
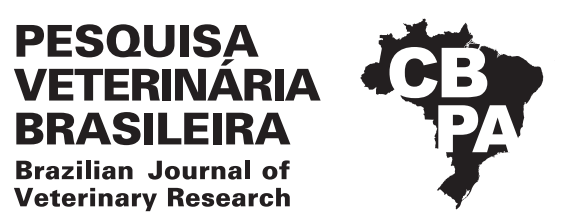

Pesq. Vet. Bras. 39(1):47-51, janeiro 2019 DOI: $10.1590 / 1678-5150-P V B-5787$

ISSN 0100-736X (Print) ISSN 1678-5150 (Online)

\title{
Neuron-specific enolase as biomarker for possible neuronal damage in dogs with distemper virus ${ }^{1}$
}

\author{
Bruno Cesar Elias ${ }^{2}$, Alice F. Alfieri ${ }^{3}$, Italmar T. Navarro ${ }^{3}$ and Lucas A. Gomes ${ }^{3 *}$ (1)
}

\begin{abstract}
Elias B.C., Alfieri A.F., Navarro I.T. \& Gomes L.A. 2019. Neuron-specific enolase as biomarker for possible neuronal damage in dogs with distemper virus. Pesquisa Veterinária Brasileira 39(1):47-51. Departmento de Clínicas Veterinárias, Faculdade de Medicina Veterinária, Universidade Estadual de Londrina, Rodovia Celso Garcia Cid PR-445 Km 380, Cx. Postal 10.011, Campus Universitário, Londrina, PR 86057-970, Brazil. E-mail: lagomes@uel.br

Neuron-specific enolase (NSE) is a biomarker of neuronal cell lysis, which demonstrates stability in extracellular fluids such as blood and cerebrospinal fluid. To the authors knowledge there is no research information comparing the use of NSE in dogs with and without encephalitis, putting in evidence the importance of that biomarker to detect neuronal damage in dogs. The objective was to compare the serum NSE levels in dogs with and without encephalitis, and to determine the serum NSE levels in normal dogs. Thirty eight dogs were evaluated, 19 dogs with encephalitis (EG Group) and 19 dogs without encephalitis (CG Group). The criteria for inclusion in the EG Group were presence of neurological signs in more than one part of the CNS (multifocal syndrome) and positive molecular diagnosis for canine distemper virus; for the CG Group were an age between 1 to 7 years and be clinically normal; NSE were measured in serum using an ELISA assay, and the results were compared. In the EG Group the NSE values were higher with significant difference $(\mathrm{P}=0.0053)$ when compared with the CG Group. NSE is a biomarker that can be measured in serum samples of dogs to monitor neuronal lesions in encephalitis.
\end{abstract}

INDEX TERMS: Neuron-specific enolase, neuronal damage, dogs, distemper virus, brain, biomarkers, neurology, inflammation, central nervous system.

RESUMO.- [Enolase neuronal específica como um possível biomarcador para lesão neuronal em cães com cinomose.] Enolase neuronal específica (NSE) é um biomarcador de lise de neurônios, que demonstra estabilidade em fluidos extracelulares como sangue e líquido cerebrospinal. Para o conhecimento dos autores, não há informações de pesquisa que comparem o uso de NSE em cães com e sem encefalite, evidenciando a importância desse biomarcador para detectar danos neuronais em cães. 0 objetivo foi comparar os níveis séricos de NSE em cães com e sem encefalites, e determinar os níveis séricos de NSE em cães saudáveis. Trinta e oito cães foram avaliados, 19 cães com encefalites (Grupo EG) e 19 cães sem encefalite (Grupo CG). 0 critério para inclusão

\footnotetext{
${ }^{1}$ Received on June 15, 2018.

Accepted for publication on August 29, 2018.

${ }^{2}$ Post-Graduate Program in Animal Science, Departamento de Clínicas Veterinárias, Faculdade de Medicina Veterinária, Universidade Estadual de Londrina (UEL), Rodovia Celso Garcia Cid PR-445 Km 380, Londrina, PR 86057-970, Brazil.

${ }^{3}$ Faculdade de Medicina Veterinária, UEL, Rodovia Celso Garcia Cid PR-445 Km 380, Londrina, PR 86057-970. *Corresponding author: lagomes@uel.br
}

no Grupo EG foi presença de sinais neurológicos em mais de uma estrutura do SNC (síndrome multifocal) e positividade no diagnóstico molecular para o vírus da cinomose canina; para o Grupo CG foi idade entre 1 e 7 anos e ser clinicamente normal; NSE foram mensuradas em amostras séricas usando o método de ELISA, e os resultados comparados. No Grupo EG os valores de NSE foram altos com diferença significativa $(\mathrm{P}=0.0053)$ quando comparado com o Grupo CG. NSE é um biomarcador que pode ser mensurado em amostras séricas de cães para monitorar lesões neuronais em encefalites.

TERMOS DE INDEXAÇÃO: Enolase neuronal, lesão neuronal, caninos, cinomose, cérebro, biomarcadores, neurologia, inflamação, sistema nervoso central.

\section{INTRODUCTION}

Neuron-specific enolase (NSE) is an intracytoplasmic glycolytic enzyme found in neurons and in neuroendocrine cells (Marangos \& Schmechel 1987) and is considered a major neuronal injury biomarker in human medicine (Yokobori et al. 2013). However, 
there are few studies on NSE in veterinary medicine (Nishida 2014). This enzyme can be found in cerebrospinal fluid (CSF) and serum, and several studies are currently investigating whether it is a predictive prognosis factor in human medicine (Chabok et al. 2012, Fendler et al. 2015, Xue et al. 2015). In cases of CNS inflammation in human beings, NSE were elevated either in serum as in CSF, but the values were superior for CSF in comparison (Lima et al. 2004). Erythrocytes and platelets also express NSE; therefore, hemolysis can cause alterations in NSE levels in the serum and this can be a condition to false positive results when NSE is elevated in serum samples (Day \& Thompson 1984, Planche et al. 2010).

In a study comparing the results of proteomic analysis in CSF from healthy dogs and dogs with meningoencephalitis of unknown origin, NSE was present in both groups but the meningoencephalitis group demonstrated increased levels (Nakamura et al. 2012). However, these results do not suggest that the biomarker can be used as a diagnostic method since NSE is related to encephalitis and not specifically to etiology. A study assessing biomarkers in dogs with gangliosidosis, a neurodegenerative disease with a progressive chronic nature, showed higher NSE values in CSF of the disease group compared to controls, suggesting that the biomarker was efficient to monitor brain lesions (Satoh et al. 2007). Although most studies evaluating NSE levels in dogs use CSF samples, one study used the presence of biomarkers in serum and CSF samples to assess brain damage in dogs undergoing cardiac arrest. They observed that NSE values in CSF and serum are elevated one and two hours after the reestablishment of circulation, respectively (Usui et al. 1994).

In Brazil, the prevalence of canine distemper in dogs with encephalitis is high (Fighera et al. 2008, Sonne et al. 2009). The CNS disease manifestations can be variable and are named as young dog encephalitis, adult dog encephalitis, old dog encephalitis, post-vaccination encephalitis, and poliencefalite with corpuscle inclusion of distemper (Headley \& Graça 2000, Headley et al. 2009, 2012). The neurological symptoms caused by the virus may be variable according to the location of the lesion (Summers et al. 1984) and the immune response (Beineke et al. 2009).

In this study, it was hypothesized two points: the first one is that dogs with distemper encephalitis express NSE in the blood; the second one is that dogs with encephalitis have increased serum levels of NSE when compared to normal dogs, indicating that NSE may be a potential biomarker that can be used to identify and monitor encephalitis. Thus, the aims of this study were to evaluate the levels of NSE in serum samples of dogs with and without encephalitis and to compare the values obtained.

\section{MATERIALS AND METHODS}

Ethics statement. In this study were included a total of 38 dogs from a Veterinary Teaching Hospital in South Brazil (Canis familiaris Linnaeus, 1758) and were separated into two groups: dogs without encephalitis denominated as control group (CG), and dogs with encephalitis denominated as encephalitis group (EG), each one with 19 dogs. The study was approved by the Ethics Committee from the University.

Study design. The inclusion criteria for dogs in the CG Group were age between 1 and 7 years, no restrictions about sex or breed, normal clinical examination and laboratory tests (blood count, creatinine, BUN, glucose, alanine aminotransferase, alkaline phosphatase). For all dogs in this group, serum samples were obtained for NSE measurement. For the EG Group, the inclusion criteria were no restriction about sex or breed, presence of neurological signs compatible, as well as be positive for canine distemper virus using molecular diagnostic (RT-PCR for the N gene of canine distemper virus). For EG Group was obtained venous blood sample, urine when available, and a CSF tap from the cisterna magna only for dogs that were euthanized by the owner's request. The time taken for all procedures for material storage and processing did not exceed $60 \mathrm{~min}$. No serum samples that presented hemolysis were included.

Measurement of serum NSE. To determine the serum values of NSE by ELISA, the samples were stored at $-80^{\circ} \mathrm{C}$. Processing of samples, as well as standards and control samples of the kit, was performed in duplicate in a single step following the guidelines of the human Neuron-Specific Enolase commercial test $\left(\right.$ ALPCO $^{\circledR}$, NSEHU-43-E01).

Distemper virus encephalitis characterization and diagnosis. For diagnosis of encephalitis, a neurological examination was performed to identify neurological signs compatible with multifocal syndrome. The dogs with neurological signs should be positive to distemper virus PCR test (Fig.2). The presence of the virus was confirmed by RT-PCR (primer designed to amplify the N gene for canine distemper) using urine or blood samples in EDTA. All samples were stored at $-80^{\circ} \mathrm{C}$ (Boom et al. 1990, Frisk et al. 1999, Amude et al. 2006).

Statistics. The statistical analysis was performed using the Kruskal-Wallis test to evaluate the differences between the NSE mean for the CG and EG Groups, with the significance level set at $5 \%(\mathrm{p}<0.05)$. A t-test was used to analyze the other comparisons with the same significance level.

\section{RESULTS \\ NSE values of serum samples}

The ELISA test developed to be used for human samples demonstrated to be efficient to detect NSE in dog's serum samples.

Comparison of NSE values between the groups showed a significant difference $(\mathrm{P}=0.0053)$, as shown in Figure 1. For the CG Group, NSE results were as follows: mean $\pm \mathrm{SD}=10.43 \pm 5.94 \mathrm{ng} / \mathrm{ml}$, median $8.53 \mathrm{ng} / \mathrm{ml}$. For the EG Group, the values were as follows: mean $\pm \mathrm{SD}=71.73 \pm 104.2 \mathrm{ng} / \mathrm{ml}$, median $=26 \mathrm{ng} / \mathrm{ml}$ (Table 1 ). When comparing the NSE values between individuals of the same group, there was no significant difference between males (CG: mean $\pm \mathrm{SD}=11.84 \pm 7.39 \mathrm{ng} / \mathrm{ml}$, median $=7.39 \mathrm{ng} / \mathrm{ml}$; EG: mean $\pm S D=44.62 \pm 64.46 \mathrm{ng} / \mathrm{ml}$, median $=20.3 \mathrm{ng} / \mathrm{ml}$ ) and females (CG: mean $\pm \mathrm{SD}=9.62 \pm 5.09 \mathrm{ng} / \mathrm{ml}$, median $8.88 \mathrm{ng} / \mathrm{ml}$; EG: mean $\pm S D=87.54 \pm 121.49 \mathrm{ng} / \mathrm{mL}$, mean $=34.29 \mathrm{ng} / \mathrm{ml}$; CG: $P=00: 50$; EG: $P=0.33$ ).

\section{Neurological findings}

All dogs with encephalitis exhibited more than one neurological signs corresponding to more than one affected neuroanatomical structure and was therefore classified as a multifocal syndrome. From the dogs in EG Group 6/19 (32\%) had lesions in the forebrain and brainstem; 4/19 (21\%) had lesions in the forebrain, brainstem and spinal cord; $3 / 19$ (16\%) had lesions in the brain stem and spinal cord; $2 / 19$ dogs (11\%) had lesions in the forebrain and spinal cord; $2 / 19(11 \%)$ had lesions in the forebrain, cerebellum and spinal cord; $1 / 19$ (5\%) had lesions in the forebrain, brain stem, and cerebellum; and 1/19 (5\%) had lesions in the forebrain and 
cerebellum (Table 2). Urine samples revealed that all dogs were positive for canine distemper.

CSF taps were obtained from $7 / 19$ (37\%) dogs whose owners requested euthanasia, and results demonstrated elevated protein levels in all cases and lymphocytic pleocytosis in $5 / 7$ (71\%) dogs (Table 2).

\section{DISCUSSION}

Dogs with encephalitis had significantly higher NSE values compared to dogs without encephalitis $(p=0.0053)$, demonstrating that NSE is a potential biomarker that can be used to detect and monitor encephalitis in dogs like the same used for humans with encephalitis. The results in this work

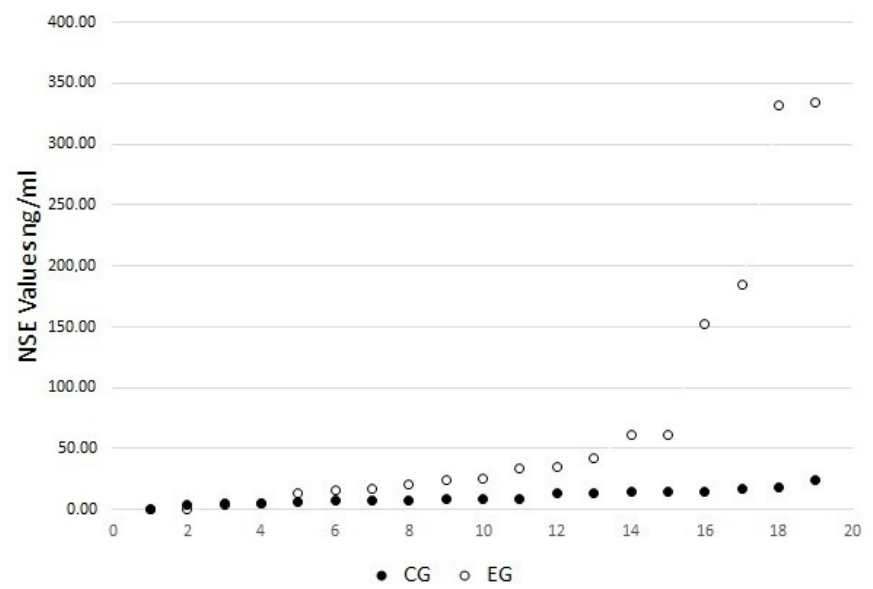

Fig.1. Scatter chart of the neuron-specific enolase (NSE) values of the groups with and whithout encephitis. Control group (CG), encephalitis group (EG).

Table 1. Summary of the statistical analysis of the serum samples of CG and EG dogs

\begin{tabular}{cccc}
\hline \multirow{2}{*}{ Group } & \multicolumn{2}{c}{ NSE $(\mathrm{ng} / \mathrm{ml})$} & \multirow{2}{*}{$\mathrm{P}$} \\
\cline { 2 - 3 } & Mean +- SD & Median & \\
\hline GS & $10.43+-5.94$ & 8.53 & 0.005299 \\
GE & $71.73+-104.2$ & 26 &
\end{tabular}

$\mathrm{CG}=$ Group without encephalitis, $\mathrm{EG}=$ encephalitis group,$+-\mathrm{SD}=$ standard deviation, $\mathrm{P}=$ value of $\mathrm{p}$ usually Kruskal-Wallis test indicated that the method used to detect NSE for humans was also effective in the measurement of NSE in dog's serum samples. Regarding to this it is important to emphasize that serum NSE can be used as an indicator of brain damage in dogs with encephalitis. This result is in agreement with a study conducted by Lima et al. (2004) when the authors tested the expression of NSE in serum samples of human beings with encephalitis and detected that this biomarker was present in high levels when compared to patients without this problem. Besides that, the ELISA test developed to be use for human samples demonstrated to be efficient to detect NSE in serum samples of dogs, which represents a cheap method to be used in veterinary practice.

In the herein study, the elevation in NSE serum levels was resultant of the brain inflammation (encephalitis) which occurred naturally by distemper virus infection. Considering this, it seems to be clear that the detection of NSE in serum is an effective tool for identification of brain inflammation in dogs in the majority of the cases.

Another important advantage in measuring NSE in the serum is the noninvasive characteristic of this procedure, which only requests a simple blood sample when compared to CSF collection. Regarding to this, measurement of NSE in serum can be a safe method to evaluate patients with encephalitis progressively, similar to what Satoh et al. (2007) and Nakamura et al. (2012) did using CSF samples, thus, representing to be a good alternative.

In a study with human, it was found that NSE was only detected in cases of injury to gray matter, but not in cases of injury to white matter (Marangos \& Schmechel 1987). Based on this, it is possible to suggest that herein in this study; the elevation of NSE in serum was associated to damage to the gray matter due to the presence of distemper virus. In addition, NSE release in the blood is associated with a neuronal death process (Marangos \& Schmechel 1987), and subsequent overflow to the CSF and later in the blood (Usui et al. 1994). While biokinetic concentration is associated with the time required for clearance of blood biomarkers (Usui et al. 1994), thus, acute cases may be associated with higher and increasing concentrations of NSE (Choi et al. 2016), once chronic diseases may not result in changes due to the amount of protein released (Satoh et al. 2007). Regarding to this, the results herein for dogs with high serum levels of NSE might be suggest that the patients were in the acute phase of the disease.

In EG, there was a high standard deviation, the highest NSE value was $334.16 \mathrm{ng} / \mathrm{ml}$ and the lowest was $0 \mathrm{ng} / \mathrm{ml}$.

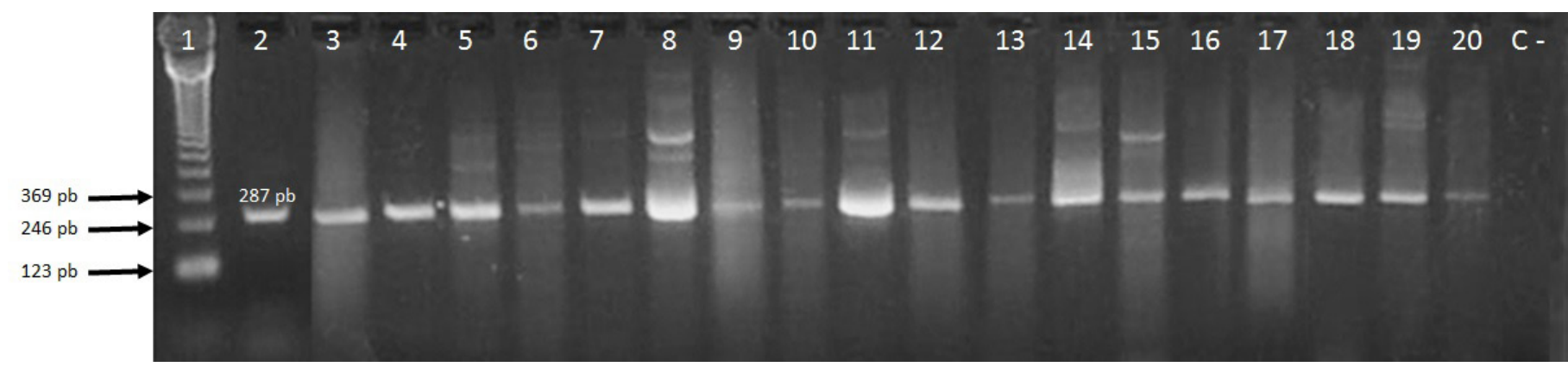

Fig.2. RT-PCR assay designed to amplify a 287 bp fragment of CDV N gene. Ladder $123 \mathrm{bp}$, Invitrogen ${ }^{\mathrm{TM}}$ Life Technologies $^{\circledR}$, USA (lane 1 ). Urine samples (lanes 2-12). Whole blood samples (lanes 13-20). Negative control using ultrapure water treated with diethylpyrocarbonate (DEPC), Invitrogen ${ }^{\mathrm{TM}}$ Life Technologies $^{\circledR}$, USA (line C-). 
Table 2. Signalment, neuroanatomical diagnosis, CSF analysis and NSE values of the EG Group

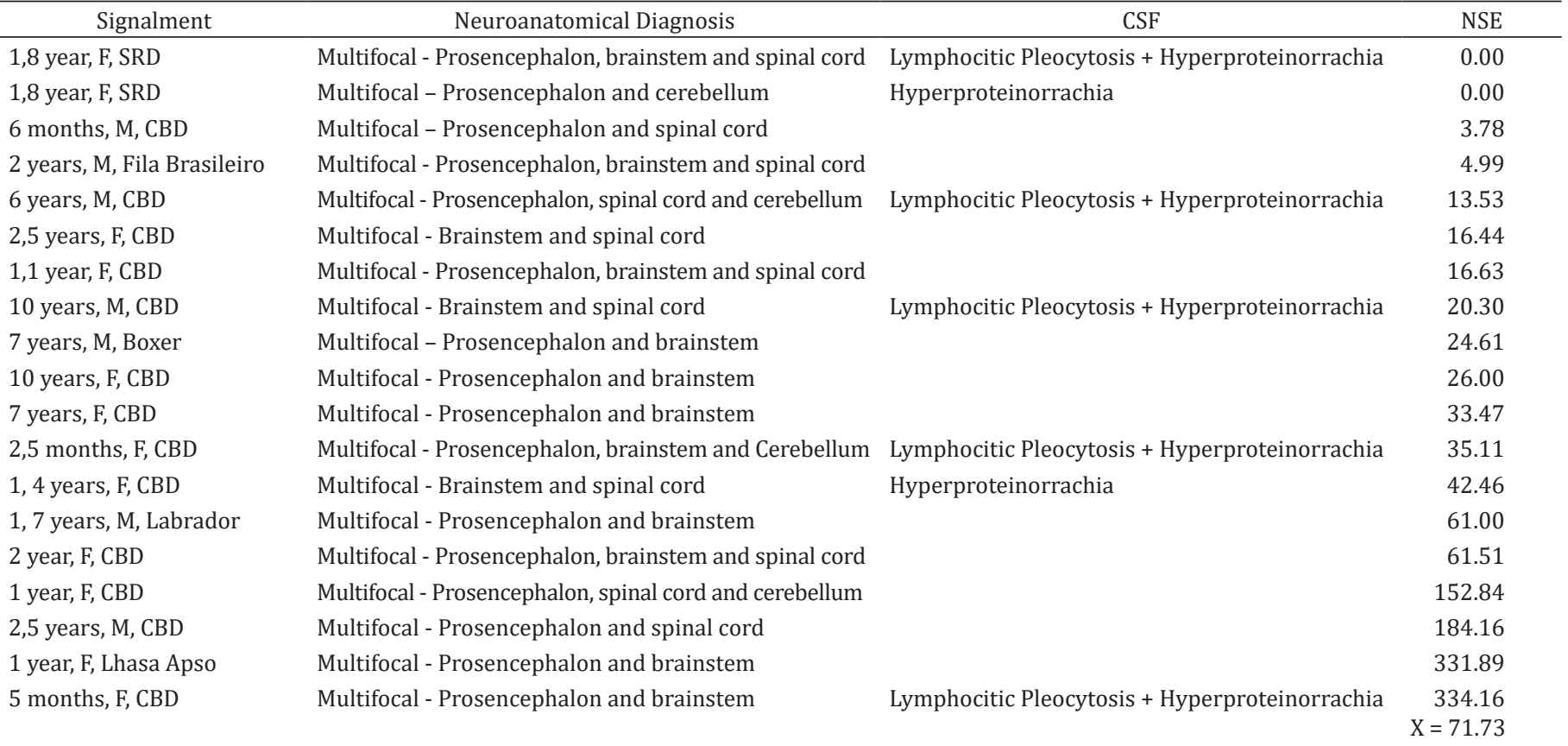

$\overline{E G}=$ Encephalitis group, $\mathrm{CSF}=$ cerebral spinal fluid, $\mathrm{NSE}=$ neuronal específic enolase, $\mathrm{CBD}=$ crossbreed, $\mathrm{F}=$ female, $\mathrm{M}=$ male.

An explanation for this lower value would be the possible chronicity in the evolution of brain inflammation, reinforcing the hypothesis that false negative results in serum measurement of serum NSE may occur in dogs with neurological signs characterized by encephalitis, thus characterizing one of the limitations of the test.

In this study, CSF samples were obtained only from dogs that the owner requested euthanasia because of the poor prognosis related to the neurological signs. The CSF samples would be a good form to compare the results obtained by the NSE samples, however, there are at least two limitations regarding to this: the first one is related to ethical aspects, once would not be possible to obtain a CSF tap from the dogs without encephalitis (considered normal) in the CG; the second one, which is a consequence of the first one and is related to a lack of results to compare the NSE values in the CSF tap from the dogs with encephalitis in the EG.

\section{CONCLUSION}

The test used was able to detect neuron-specific enolase (NSE) in serum samples of dogs and that the values were increased in most of the EG Group animals when compared to CG Group. False-negative results may also occur.

Conflict of interest statement. The authors no have competing interests.

\section{REFERENCES}

Amude A.M., Alfieri A.A. \& Alfieri A.F. 2006. Antemortem diagnosis of CDV infection by RT-PCR in distemper dogs with neurological deficits without the typical clinical presentation. Vet. Res. Commun. 30(6):679-687. <http:// dx.doi.org/10.1007/s11259-006-3308-2><PMid:16838210>

Beineke A., Puff C., Seehusen F. \& Baumgärtner W. 2009. Pathogenesis and immunopathology of systemic and nervous canine distemper. Vet.
Immunol. Immunopathol. 127(1/2):1-18. <http://dx.doi.org/10.1016/j. vetimm.2008.09.023><PMid:19019458>

Boom R., Sol C.J., Salimans M.M.M., Jansen C.L., Wertheim-van Dillen P.M., van der Noordaa J. 1990. Rapid and simple method for purification of nucleic acids. J. Clin. Microbiol. 28(3):495-503. <PMid:1691208>

Chabok S.Y., Moghadam A.D., Saneei Z., Amlashi F.G., Leili E.K. \& Amiri Z.M. 2012. Neuron-specific enolase and $\mathrm{S100BB}$ as outcome predictors in severe diffuse axonal injury. J. Trauma Acute Care Surg. 72(6):1654-1657. <http://dx.doi.org/10.1097/TA.0b013e318246887e><PMid:22695436>

Choi S., Park K., Ryu S., Kang T., Kim H., Cho S. \& Oh S. 2016. Use of S-100B, NSE, CRP and ESR to predict neurological outcomes in patients with return of spontaneous circulation and treated with hypothermia. Emerg. Med. J. 33(10):690-696. <http://dx.doi.org/10.1136/emermed-2015-205423> <PMid:27287003>

Day I.N.M. \& Thompson R.J. 1984. Levels of immunoreactive aldolase C, creatine kinase-BB, neuronal and non-neuronal enolase, and 14-3-3 protein in circulating human blood cells. Clin. Chim. Acta 136(2/3):219-228. <http://dx.doi.org/10.1016/0009-8981(84)90295-X><PMid:6692576>

Fendler W.P., Wenter V., Thornton H.I., Ilhan H., von Schweinitz D., Coppenrath E., Schmid I., Bartenstein P. \& Pfluger T. 2015. Combined scintigraphy and tumor marker analysis predicts unfavorable histopathology of neuroblastic tumors with high accuracy. PLoS One 10(7):e0132809. <http://dx.doi. org/10.1371/journal.pone.0132809><PMid:26177109>

Fighera R.A., Souza T.M., Silva M.C., Brum J.S., Graça D.L., Kommers G.D., Irigoyen L.F. \& Barros C.S.L. 2008. Causas de morte e razões para eutanásia de cães da Mesorregião do Centro Ocidental Rio-Grandense (1965-2004). Pesq. Vet. Bras. 28(4):223-230. <http://dx.doi.org/10.1590/S0100736X2008000400005>

Frisk A.L., König M., Moritz A. \& Baumgärtner W. 1999. Detection of canine distemper virus nucleoprotein RNA by reverse transcription-PCR using serum, whole blood, and cerebrospinal fluid from dogs with distemper. J. Clin. Microbiol. 37(11):3634-3643. <PMid:10523566> 
Headley S.A. \& Graça D.L. 2000. Canine distemper: epidemiological findings of 250 cases. Braz. J. Vet. Res. Anim. Sci. 37(2):1-9. <http://dx.doi.org/10.1590/ S1413-95962000000200009>

Headley S.A., Amude A.M., Alfieri A.F., Bracarense A.P.F.R.L., Alfieri A.A. \& Summers B.A. 2009. Molecular detection of Canine distemper virus and the immunohistochemical characterization of the neurologic lesions in naturally occurring old dog encephalitis. J. Vet. Diagn. Invest. 21(5):588-597. <http://dx.doi.org/10.1177/104063870902100502><PMid:19737753>

Headley S.A., Amude A.M., Alfieri A.F., Bracarense A.P.F.R.L. \& Alfieri A.A. 2012. Epidemiological features and the neuropathological manifestations of canine distemper virus-induced infections in Brazil. Semina, Ciênc. Agrárias 33:1945-1978.

Lima J.E., Takayanagui O.M., Garcia L.V. \& Leite J.P. 2004. Use of neuron-specific enolase for assessing the severity and outcome of neurological disorders in patients. Braz. J. Med. Biol. Res. 37(1):19-26. <http://dx.doi.org/10.1590/ S0100-879X2004000100003><PMid:14689039>

Marangos P.J. \& Schmechel D.E. 1987. Neuron specific enolase, a clinically useful marker for neurons and neuroendocrine cells. Annu. Rev. Neurosci. 10(1):269-295. <http://dx.doi.org/10.1146/annurev.ne.10.030187.001413> $<$ PMid:3551759>

Nakamura K., Miyasho T., Nomura S., Yokota H. \& Nakade T. 2012. Proteome analysis of cerebrospinal fluid in healthy beagles and canine encephalitis. J. Vet. Med. Sci. 74(6):751-756. <http://dx.doi.org/10.1292/jvms.11-0474> $<$ PMid:22251802>

Nishida H. 2014. Biomarkers for neural injury and infection in small animals. Vet. Clin. N. Am., Small Anim. Pract. 44(6):1187-1199. <http://dx.doi. org/10.1016/j.cvsm.2014.07.014 ><PMid:25199840>
Planche V., Brochet C., Bakkouch A. \& Bernard M. 2010. Importance of hemolysis on neuron-specific enolase measurement. Ann. Biol. Clin. 68(2):239-242. <PMid:20348052>

Satoh H., Yamato O., Asano T., Yonemura M., Yamauchi T., Hasegawa D., Orima H., Arai T., Yamasaki M. \& Maede Y. 2007. Cerebrospinal fluid biomarkers showing neurodegeneration in dogs with GM1 gangliosidosis: possible use for assessment of a therapeutic regimen 3. Brain Res. 1133(1):200208. <PMid:17196562>

Sonne L., Oliveira E.C., Pescador C.A., Santos A.S., Pavarini S.P., Carissimi A.S \& Driemeier D. 2009. Achados patológicos e imuno-histoquímicos em cães infectados naturalmente pelo vírus da cinomose canina. Pesq. Vet. Bras. 29(2):143-149. <http://dx.doi.org/10.1590/S0100-736X2009000200010>

Summers B.A., Greisen H.A. \& Appel M.J.G. 1984. Canine distemper encephalomyelitis: variation with virus strain. J. Comp. Pathol. 94(1):65-75 <http://dx.doi.org/10.1016/0021-9975(84)90009-4><PMid:6699231>

Usui A., Kato K., Murase M., Hotta T., Tanaka M., Takeuchi E. \& Abe T. 1994. Neural tissue-related proteins (NSE, G0 alpha, 28-kDa calbindin-D, S100b and CK-BB) in serum and cerebrospinal fluid after cardiac arrest. J. Neurol. Sci. 123(1/2):134-139. <http://dx.doi.org/10.1016/0022-510X(94)90215-1> $<$ PMid:8064306>

Xue F., Zhu L., Wang L. \& Wang Q. 2015. Serum neuron specific enolase levels correlate with patient prognosis for advanced lung cancer. Int. J. Clin. Exp. Med. 8(6):9498-9504. <PMid:26309614>

Yokobori S., Hosein K., Burks S., Sharma I., Gajavelli S. \& Bullock R. 2013. Biomarkers for the clinical differential diagnosis in traumatic brain injury, a systematic review. CNS Neurosci. Ther. 19(8):556-565. <http://dx.doi. org/10.1111/cns.12127><PMid:23710877> 